\title{
INTERNACIONALIZAÇÃO: QUEM VAI ENCARAR?
}

LUÍS HENRIQUE PEREIRA, professor da FGV-EAESP, luis.pereira@fgv.br

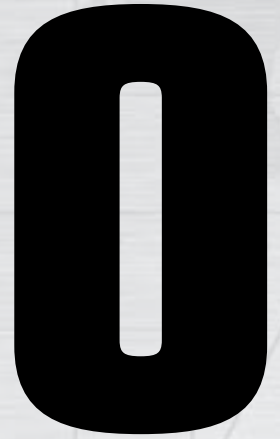

s motivos que levam uma empresa a investir na internacionalização de suas operações são muitos, e variam desde aqueles mais estratégicos, tais como o aproveitamento de novas oportunidades, aquisição de novos conhecimentos e conquista de novos mercados, até os mais reativos, como o atendimento a um importante cliente que expandiu suas operações para o exterior ou o acompanhamento de empresas multinacionais, onde quer que elas estabeleçam suas plantas industriais.

Historicamente, as empresas brasileiras sempre andaram na contramão da internacionalização e poucas foram aquelas que se lançaram ao mundo até 1970. Foi somente a partir desse período que alguns heroicos exemplos, como Gerdau, Weg, Sabó, Marco Polo, Vale, Odebrecht e Camargo Correa, aventuraram-se em terras estrangeiras. Os motivos pelos quais as empresas brasileiras não se internacionalizavam eram vários e, de certa forma, compreensíveis, na medida em que a demanda do mercado interno era grande e as empresas mal davam conta de atendê-la. Os juros altos, a hiperinflação e a escassez de crédito impingiam um ônus demasiadamente pesado às empresas e anulavam qualquer possibilidade de competição no mercado internacional.
Somente na década de 1990, principalmente a partir do Plano Real e da consequente estabilização da economia, outras empresas brasileiras partiram em busca de novos mercados. Esse processo deu-se por vários motivos e, entre outros, destacam-se o acesso a fatores de produção com menor custo ou maior valor, acesso a fontes mais próximas de suprimento e diversificação de risco.

Naquele momento, novas empresas passaram a vislumbrar oportunidades em mercados internacionais. Em um primeiro estágio, percebeu-se um envolvimento mais lento e gradual, com o aumento das exportações e investimentos em parceiros comerciais em países estrangeiros, notadamente na América Latina. O movimento foi se consolidando e algumas empresas passaram a realizar investimentos diretos por meio de joint ventures, fusões e aquisições e, até mesmo, por investimentos do tipo greenfield. Destacam-se nesse processo empresas ligadas ao agronegócio e indústria de alimentos, tais como JBS-Friboi e BR Foods, bem como empresas ligadas à indústria siderúrgica e extração de minérios, como Gerdau e Vale.

O tradicional setor da construção civil expandiu mais ainda seus investimentos internacionais, e outros setores, como bens de consumo e serviços, passaram a integrar a lista das principais empresas brasileiras com investimento direto no exterior. Empresas do setor de serviços ligados à tecnologia de automação bancária e de 
varejo tornaram-se atores importantes em seus respectivos mercados. Outro setor de destaque é o de franquias, em que marcas como Via Uno, Arezzo e Hering expandiram seus negócios e alcançaram patamares importantes de crescimento em suas operações internacionais.

Apesar do crescimento do Investimento Direto no Exterior (IDE) feito por empresas brasileiras na última década, é importante notar que grande parte desses investimentos foi realizada ou incentivada pelo governo federal, como nos casos da Petrobrás, cujo controle é majoritariamente estatal, e da JBS-Friboi, em que o BNDES financiou grande parte das aquisições da empresa nos Estados Unidos, Itália e Austrália.

Após a crise de 2008, muitos governos, notadamente das economias mais desenvolvidas, fecharam-se aos investimentos externos e procuraram proteger suas economias com medidas intervencionistas que tornaram mais difícil a entrada de empresas e produtos estrangeiros. Diante de um cenário de turbulência na economia mundial, a questão que se levanta sobre a internacionalização de empresas brasileiras é se elas serão capazes de desenvolver competências que levem à maior vantagem competitiva e, consequentemente, ao crescimento e à geração de valor.

As empresas de países emergentes, pelo fato de operarem em países cujas economias ainda não foram abaladas pela crise, possuem, por um lado, uma chance extraordinária de ganhar espaço no cenário mundial, mas, por outro, correm o risco de que as economias combalidas não se recuperem rapidamente e acabem tragando consigo as economias emergentes. Por que se arriscar neste momento em investimentos no exterior, onde as dificuldades são enormes e as experiências de insucesso, incontáveis? Teriam as empresas brasileiras as competências necessárias para obter sucesso em mercados internacionais? Algumas já demonstraram que sim, porém outras precisam avançar. As cartas estão na mesa, quem arrisca a próxima jogada?

\section{$\boldsymbol{\sim}$ AS EMPRESAS BRASILEIRAS DEVEM AVALIAR CUIDADOSAMENTE SUAS CAPACIDADES E COMPETÊNCIAS AO DECIDIREM PELA ENTRADA OU MAIOR ENVOLVIMENTO EM MERCADOS INTERNACIONAIS}

